\title{
Factors Motivating Employee Loyalty and Employee Retention in Deposit Money Banks in Nigeria
}

\author{
Adedeji, Abosede O. (Correspondence author) \\ Department of Business Administration, \\ Federal University of Technology Akure, Nigeria \\ Ugwumadu, Obianuju C. \\ Department of Project Management Technology, \\ Federal University of Technology Akure, Nigeria
}

Received: July 15, 2018 Accepted: August 20, 2018 Online published: August 27, 2018

doi:10.5296/ijhrs.v8i3.13555 URL: https://doi.org/10.5296/ijhrs.v8i3.13555

\begin{abstract}
For some time, the banking sector in Nigeria has been witnessing incessant labour turnover. The study focused on the factors motivating employee loyalty and employee retention in the deposit money banks. This study used descriptive survey research design. Four banks namely First Bank of Nigeria, United Bank for Africa, Guaranty Trust Bank and First City Monument Bank were randomly selected for the study. The sample size for the study consists of 190 employees out of the total population of 360 employees. A set of self constructed questionnaire was used for data collection. 118 copies of the questionnaire that were correctly completed out of the 190 copies which were administered were used for the study. Percentages, frequency and mean ranking were used to analyze the data collected. The result showed that training and development (3.95) and promotion (3.86) were the main motivating factors for employee loyalty while training and development (4.01) and job security (3.90) were the best ranked employee retention factors. The implication of the result is that, apart from training and development, the better motivating factors for employee loyalty and employee retention are not the same. The result of the hypothesis showed a strong positive relationship between employee retention and loyalty factors in deposit money banks $(r=0.83)$. It is recommended that management should provide quality training and development programmes as important motivating factors for both employee loyalty and employee retention. The inclusion of other major motivating factors in the organizations' HRM policy will be an added advantage.
\end{abstract}


Keywords: employee loyalty, employee retention, motivating factors

\section{Introduction}

Labour turnover appears to be rampant in the deposit money banks previously known as commercial banks in Nigeria, resulting in employees seeking better opportunities in organizations within and outside the country. With the dearth of qualified personnel probably occasioned by the abundance of unemployable graduates, employee loyalty and retention become very important. Good employees ought to be retained and this may depend on their loyalty to the organization. This is as a result of many organizations trying to attract and recruit highly priced and competitive employees because they add value to their employers. To obtain employees' loyalty and retention so that they are not poached by competitors, there is the need for employers of labour to provide factors that motivate the employees to stay on. Employee loyalty and retention are factor-based but there has been no agreement on the generally acceptable factors that motivate staff to be loyal and stay on the job.

Uzma(2015) opined that employees are assets to every organization and they are the main factor of any organizational progress. Although employee loyalty and retention are issues in human resource management but they are particularly important in the deposit money banks in Nigeria that appears to be volatile. Employee loyalty and retention need to be studied because the deposit money banks in Nigeria have just endured economic recession, unstable forex regime, huge non- performing loans and unpredictable corporate governance (Adedeji, 2018). The loyalty and retention of the human capital need to be examined since good employees are not easily replaced without costs. Therefore, good employees could mean good and profitable organizations.

According to the National Bureau of Statistics (2010), many factors have led to some qualified personnel who possess the right knowledge, skills and abilities to leave banking and find greener opportunities in other lucrative sectors of the Nigerian economy. Perhaps, longer working hours, increased workload, poor managerial style, job insecurity, poor working environment, dissatisfaction with rewards and recognition, and lack of work-life balance have been responsible for the incessant turnover in the sector. The perceived lack of career progression has also been a contentious issue in the deposit money banks and banking industry in Nigeria. Eight years after the report, labour turnover have not abated in the banks. All these factors have made employee retention a major issue of discuss in the sector. It behooves on management and other stakeholders to come up with strategies that will encourage employee retention in the banks since their retention reduces cost of recruitment. Adding employee disloyalty and not-to-stay decision to the myriads of challenges plaguing the banks should be avoided because disloyal and unstable workforce may be detrimental to their employers. One begins to imagine which factors will enhance loyalty and retention among employees of the deposit money banks in Nigeria in this time of economic uncertainty.

In other words, finding and retaining the best employees is every company's challenge (Mehta, Singh, Bhakar \& Sinha, 2010). Based on current happenings in the workplace, it could be envisaged that in the future, successful organizations would be those that adapt their 
organizational behaviour to innovation, creativity and flexibility; achieved by employee loyalty and retention. Loyal employees utilize their skills, knowledge, expertise, talent and other attributes for the benefit of the organizations they work for and can go extra mile to ensure the survival of the workplace through excellent performance.

According to Mwangi and Omondi (2016) staff retention is one of the key challenges facing many organizations around the world. Human resource managers are tasked with the responsibility of coming up with viable and better strategies to attract, retain and motivate staff, in order to achieve both employee and organizational goals and objectives (Kassa, 2015). Employee retention is a key factor in an organization's success (Lyria, 2013). It affects both public and private organizations occasioned by globalization that has intensified competition and increased mobility of highly skilled employees (Ng'ethe, 2013).

According to Amadasu (2003) and Gberevbie (2008), if appropriate employee retention strategies are adopted and implemented by organizations, employees will remain and work for the successful achievement of organizational goals. Nonetheless, the question of how motivation should be induced in the employees in order to maintain their loyalty to the organization still remains. The reviewed literature did not reveal the generally accepted factors that motivate bank employees' loyalty and retention. Consequently, Robbins, Judge and Sanghi (2007) explained that the question is not about if a person is motivated or not, but it is important to know the factors that motivate employees and bring about loyalty and retention willingly and without coercion. Building on Al-Ma'ani (2013), achieving a high level of organizational loyalty is one of the factors that help banks to achieve their objectives. It is a prerequisite for many modern organizations because the banks that have employees with high degree of loyalty are effective banks and thus they achieve the desired goals of significant profits and the highest performance. They also achieve additional competitive advantage as a result of retaining qualified staff in the banking sector.

The objective of this study is to examine the factors that motivate employee loyalty and retention among the employees of deposit money banks in Nigeria. This study is also to ascertain the relationship between factors motivating employee loyalty and retention in the banks.

\subsection{Research Questions}

The following research questions were asked and answered:

i. What are the factors motivating employee loyalty and retention in deposit money banks?

ii. What is the relationship between factors motivating employee loyalty and retention in deposit money banks?

\subsection{Objectives of the Study}

The specific objectives of the study are to:

i. examine the factors motivating employee loyalty and retention in deposit money banks; and 
ii. ascertain the relationship between factors motivating employee loyalty and retention in the banks.

\subsection{Research Hypothesis}

Only one null hypothesis was formulated for the study:

$\mathrm{H}_{01}$ : There is no significant relationship between employee retention factors and employee loyalty factors in the deposit money banks

\section{Literature Review}

\subsection{Conceptual Review}

\subsubsection{Concept of Retention}

Retention is defined as a voluntary move by an organization to create an environment, which engages employees for long term and with primary aim of preventing the loss of competent employees from the organization as this could have adverse effects on productivity and service delivery (Oginni, Dunmade \& Ogunwole, 2018). The retention of high performing employees has become more challenging for managers. Such employees are quite mobile and frequently move from one job to another because many organizations want to attract and poach them at a time. Luna-Arocas and Camps (2008) believe that maintaining a stable workforce is one of the key sources of sustainable competitive advantage for organizations. It is one thing to employ staff; it is another effort to retain them. Any organization that does not retain its staff will be incurring costs of recruitment, training and retraining as well as employee disloyalty. Employee retention is important to the overall success of any organization. In this study, employee retention is viewed from the perspective of employees' willingness to remain in the organization based on availability of motivating factors.

\subsubsection{Concept of Loyalty}

Kumar and Shekhar (2012) described loyalty as the willingness to put one's personal needs aside for the betterment of a relationship. It refers to a person's preparedness to defend another person or entity irrespective of the opinion of others. According to Antoncic and Antoncic (2011), employees are loyal when they believe in the objectives of the company, accept the objectives as their own, work for their common welfare, and want to stay in the company. Employee loyalty is a deliberate commitment to further the best interests of one's employer, even when doing so may demand sacrificing some aspects of one's self-interest beyond what would be required by one's legal and other moral duties. A loyal employee is such that is willing to work in that organization, thinking or believing that to work in the organization is the best option for him. For this purpose, the employee tries his best for the success of the organization to ensure that it survives.

\subsection{Theoretical Review}

This study is based on equity theory by Adam Smith. Smith (1965) in the theory posits that employees seek to maintain equity between the input that they bring into a job and the outcome they receive from it against the perceived inputs and outcomes of other employees. 
Employee input include effort, loyalty, hard work, commitment, skill, ability, adaptability, flexibility, tolerance, determination, heart and soul, enthusiasm, trust in our boss and superiors, support of colleagues and subordinates as well as personal sacrifice while the output include pay, salary, expenses, perks, benefits, pension arrangements, bonus and commission - plus intangibles - recognition, reputation, praise and thanks, interest, responsibility, stimulus, travel, training, development, sense of achievement and advancement and promotion.

Equity theory proposes that individuals who perceive themselves as either under-rewarded or over rewarded will experience distress, and that this leads to efforts to restore equity within the organization. This theory appears appropriate for this study and it is used as the theoretical framework.

\subsection{Empirical Review}

Employee loyalty and retention have attracted empirical studies recently due to their importance. Logan (2000) found that opportunity to learn and do new things enhance employee retention. It can be deduced that organizations that allow employee assertiveness and use of their initiative in carrying out their duties will enhance employee loyalty and retention. According to Clarke (2001), employees remain where there is strong relationship with colleagues in the workplace. This can be viewed from the perspective of team building for task accomplishments and interactions beyond the office. It can lead to team encouragement for the achievement of set goals.

Samuel and Chipunza (2009) studied the use of motivational variables as a panacea for employee retention and turnover reduction among employees of two private and two public sector organizations in South Africa. The study which was based on cross-sectional survey research design had a total population of 1800 employees and a sample size of 145 respondents. A self constructed questionnaire was used for data collection and Chi-square test of association was used in testing the hypothesis formulated at 0.05 level of significance. The result of the study indicated that intrinsic and extrinsic motivational factors to a very large extent influenced both private and public sector employees to remain on their job. Specifically, training and development, challenging/interesting work, freedom for innovative thinking and job security were found to influence employee retention in both private and public organizations.

Nyamekye (2012) carried out a study to investigate the impact of motivation on the retention of employees in Standard Chartered Bank, Ghana Limited. A total of 180 respondents were selected for the study and regression analysis was used for data analysis. The result of the study showed that motivational factors such as salary and fringe benefits were rated as most important to the workforce of the bank, followed by job security and relationship with co-workers. Other strategies rated important to the workforce are recognition, training opportunities, openness and trust, promotional opportunities, and effective communication.

Sinha and Sinha (2012) studied the factors affecting employee retention among 100 employees holding middle managerial positions in two organizations from heavy engineering industry in India. In EEPL three factors ranked in order of importance are competence and 
relationship oriented, scholastic and futuristic oriented and developmental and reward oriented. In MBPL, relationship oriented came first, followed by competence and scholastic oriented and thirdly by reward oriented. Also, the employees of both companies found their organizations retention factors adequate and suitable for them although the factors differ in order of importance to the employees. The implication of this result is that what is good for one set of employees may not motivate the other set based on individual differences and interests.

Khuong and Tien (2013) worked on factors that have direct and indirect influence on employee loyalty through job satisfaction among bank workers in Ho Chi Minh City (HCMC), Vietnam. The study involved 201 employees of 11 banks. Multiple regression, factor and path analyses were used to analyse the collected primary data. The study revealed that job satisfaction, organizational environment and incentives among others were related to organizational loyalty. The researchers recommended that those factors need to be provided in the workplace for employee loyalty.

Osibanjo, Salau and Falola (2014) studied the relationship between motivational factors (salary, promotion, incentives, award, relationships and benefits); employee retention and job satisfaction in the Nigerian banking industry. The survey research design was adopted and primary data were obtained through a self- administered questionnaire from the sample size of three hundred and seventy six (376) respondents. AMOS 21 Structural Equation Model (SEM) was used to analyse the data. The result showed that salary and promotion have strong positive implications for employee retention. Similarly, incentives and benefits were also found to have positive effects on job satisfaction. However, award and relationships were found to have negative effects on job satisfaction.

Dama and Isah (2015) investigated the influence of training and development on staff retention and loyalty among bank workers in Adamawa State, Nigeria. The sample size of the research was 197 and the instrument used was a set of questionnaire. Using regression for data analysis, they found that training and development positively affect staff retention and loyalty.

Mwangi and Omondi (2016) conducted their study on factors influencing staff retention in Equity Bank Limited, Kenya with 100 employees at various levels of management as study sample. Data analysis was done using descriptive statistics such as mean and standard deviation and inferential statistics that include correlation and regression analysis. The study revealed that financial and non-financial needs, reward system and training are factors driving employee loyalty.

Oginni, Dunmade and Ogunwole (2018) examined employee's work expectations, satisfaction and labour turnover in the service industry in Nigeria. Data collected with the use questionnaire from 542 respondents in three states were analyzed using correlation and regression analysis. The study found a positive and strong relationship among the variables and recommended that management should understand employees work expectations at the point of entry. This will enable management to harmonize employee job expectations with organizational expectations for the benefit of all stakeholders. The result showed positive 
linear relationship between job satisfaction and retention.

The reviewed literature showed that there is no agreement on the specific factors motivating employee loyalty and retention although some factors continued to appear as the most preferred in the studies. Perhaps the result of this study would align with the previous ones or be different.

\section{Methodology}

This study employed descriptive survey design. Four deposit money banks in Akure, Nigeria namely First City Monument Bank(FCMB), United Bank for Africa(UBA), First Bank of Nigeria(FBN) and Guaranty Trust Bank(GTB) which are the major players in banking activities and with a total population of 360 employees were investigated. Population of the study comprised all the top level, middle level and low level management staff of the banks respectively. The sample size being 190 was selected using random sampling technique. The research was based on primary data that were collected through a set of self administered questionnaire. The questionnaire contained the demographic information of respondents, statements on motivating factors, employee loyalty and employee retention. It had a five-point Likert scale rating from 1-"not important" to 5-"very important". In this study, motivating factors formed the independent variable while employee loyalty and retention formed the dependent variable. Percentages, frequencies and mean ranking were used to analyze the data collected. The hypothesis was tested at 0.05 level of significance $(\mathrm{p}<0.05)$ and analyzed using Pearson Correlation Coefficient. The Formula is given as:

$$
r=r_{x y}=\frac{n \sum x_{i} y_{i}-\sum x_{i} \sum y_{i}}{\sqrt{n \sum x_{i}^{2}-\left(\sum x_{i}\right)^{2}} \sqrt{n \sum y_{i}^{2}-\left(\sum y_{i}\right)^{2}}}
$$

Correlation coefficient, $\boldsymbol{r}$, is subject to the constraint: $\mathbf{- 1} \leq \mathbf{r} \leq+\mathbf{1}$

The closer $r_{s}$ is to \pm 1 , the stronger the monotonic relationship.

The validity of the research instrument (questionnaire) was determined using content validity approach by ensuring that the instrument clearly defined some concepts and constructs used to frame the items that highlight the concept or constructs used. The reliability of the research instrument was measured using test-retest approach to test the consistency level of the instrument employed for the study. The reliability coefficient being $\mathrm{r}=0.8$ which is adequate.

\section{Results}

\subsection{Response Rate per Bank}

The 190 copies of questionnaire were distributed to the four banks as follows: FBN 63 copies were administered with 41 retrieved, FCMB got 37 with 23 retrieved, UBA got 48 with 29 retrieved and GTB got 42 with 25 retrieved. In all 118 copies representing $62.1 \%$ were 


\section{Macrothink \\ International Journal of Human Resource Studies \\ ISSN 2162-3058 2018, Vol. 8, No. 3}

retrieved. The retrieved copies are adequate for the study.

\subsection{Demographic Information of Respondents}

The data collected showed that 86 males $(72.9 \%)$ and 32 females $(27.1 \%)$ were used as respondents. It shows that there are more male employees than female employees in the sampled banks. The reason for the disparity could not be ascertained. Their educational qualification revealed that 50 respondents (42.4\%) possessed NCE/OND certificate, 42 respondents $(35.6 \%)$ possessed Bachelor degree, 22 respondents (18.6\%) possessed Master degree and 4 respondents $(3.4 \%)$ possessed the $\mathrm{PhD}$ degree. It could be deduced that employees with NCE/OND certificates are in the majority; perhaps due to outsourcing of tellers and similar employees by some of the banks. These set of employees are semi skilled and carry out routine assignments. Graduates constitute about $36 \%$ of the workforce and are next in number to the NCE/OND holders. As skilled workers, they need to take up supervisory tasks and are usually permanent staff. It is noteworthy to observe that banks now have $\mathrm{PhD}$ holders as staff though in insignificant number. On the number of years spent so far on the current job, 74 respondents $(62.7 \%)$ have spent $0-4$ years, 40 respondents $(33.9 \%)$ have spent 5-9 years and 4 respondents $(3.4 \%$ ) have spent 10 years and above on their current job. From the analysis, about $2 / 3$ of the workforce are $0-4$ years on the job while only $3.4 \%$ are 10 years and above on the job. The data analysis tend to suggest high turnover rate within the banking industry.

\subsection{Factors Motivating Employee Loyalty in Deposit Money Banks}

Table 1 shows the perception of respondents on the importance of employee motivating factors affecting loyalty. It must be noted that all the factors are important based on the perception of the respondents. Training and development occupies the first position among the loyalty factors with a mean rank of 3.95. Other factors have the following mean rank: promotion (3.86), job security (3.78), job satisfaction (3.63) and managerial style (3.58). They came second, third, fourth and fifth respectively. The result shows that participation in decision-making (3.15), organizational values and beliefs (3.14) and reward and recognition (3.10) are not as important as the first five factors. They were the least three important factors in tenth, eleventh and twelfth positions correspondingly. 


\section{Macrothink}

International Journal of Human Resource Studies

ISSN 2162-3058

2018, Vol. 8, No. 3

Table 1. Factors Motivating Employee Loyalty in Deposit Money Banks

\begin{tabular}{llllllllll}
\hline Factors & & 1 & 2 & 3 & 4 & 5 & $\mathrm{~N}$ & Mean & Ranking \\
\hline Training and Development & $\%$ & 3.4 & 6.8 & 20.3 & 30.5 & 39.0 & 118 & 3.95 & $1^{\text {st }}$ \\
Promotion & $\%$ & 1.7 & 11.9 & 16.9 & 37.3 & 32.2 & 118 & 3.86 & $2^{\text {nd }}$ \\
Job Security & $\%$ & 5.1 & 8.5 & 13.6 & 49.2 & 23.7 & 118 & 3.78 & $3^{\text {rd }}$ \\
Job Satisfaction & $\%$ & 3.4 & 3.4 & 37.3 & 39.0 & 16.9 & 118 & 3.63 & $4^{\text {th }}$ \\
Managerial Style & $\%$ & 3.4 & 15.3 & 23.7 & 35.6 & 22.0 & 118 & 3.58 & $5^{\text {th }}$ \\
Organizational Justice and Prestige & $\%$ & 3.4 & 11.9 & 30.5 & 35.6 & 18.6 & 118 & 3.54 & $6^{\text {th }}$ \\
Work Environment & $\%$ & 13.6 & 13.6 & 8.5 & 37.3 & 27.1 & 118 & 3.51 & $7^{\text {th }}$ \\
Work-Life Balance & $\%$ & 18.6 & 16.9 & 5.1 & 27.1 & 32.2 & 118 & 3.37 & $8^{\text {th }}$ \\
Hiring practices or Employee\% & 16.9 & 13.6 & 20.3 & 30.5 & 18.6 & 118 & 3.20 & $9^{\text {th }}$ \\
$\begin{array}{l}\text { Selection } \\
\text { Participation in Decision-Making }\end{array}$ & $\%$ & 10.2 & 20.3 & 28.8 & 25.4 & 15.3 & 118 & 3.15 & $10^{\text {th }}$ \\
Organizational Values and Beliefs \\
$\begin{array}{l}\text { Reward and Recognition } \\
\text { Valid N (listwise) }\end{array}$ & $\%$ & 15.3 & 16.9 & 22.0 & 30.5 & 15.3 & 118 & 3.14 & $11^{\text {th }}$ \\
\hline
\end{tabular}

Note $1=$ not important, $2=$ of little importance, $3=$ moderately important, $4=$ important, $5=$ very important

Source: Field Survey (2018)

\subsection{Factors Motivating Employee Retention in Deposit Money Banks}

The respondents were asked to state how important the twelve factors are if they are to consider remaining in their present employment, just like the factors were rated under loyalty factors. The result as displayed in Table 2 shows that $1.7 \%$ of the respondents stated that training and development as employee retention factor is not important, 15.3\% stated that it is of little importance while $27.1 \%$ and $49.2 \%$ said that it is moderately important and very important respectively. Training and development was ranked first with mean value of 4.07 by the respondents. Job security, reward and recognition, managerial style and promotion were ranked second, third, fourth and fifth respectively with mean values of 3.90, 3.52, 3.51 and 3.46 in that order. Work environment (3.22), organizational values and beliefs (3.14) and participation in decision-making are least three important factors giving the consideration for other identified factors presented in the table. Participation in decision-making has $6.8 \%$ of not important to employee retention, $18.6 \%$ of little importance, $39 \%$ of moderately important, $25.4 \%$ of important and $10.2 \%$ of very important factors motivating employee retention. 
Table 2. Factors Motivating Employee Retention in Deposit money banks

\begin{tabular}{|c|c|c|c|c|c|c|c|c|}
\hline Factors & 1 & 2 & 3 & 4 & 5 & $\mathrm{~N}$ & Mean & Ranking \\
\hline $\begin{array}{ll}\text { Training } & \text { and } \\
\text { Development } & \end{array}$ & 1.7 & 15.3 & 6.8 & 27.1 & 49.2 & 118 & 4.07 & $1^{\text {st }}$ \\
\hline Job Security & 0.0 & 10.2 & 18.6 & 42.4 & 28.8 & 118 & 3.90 & $2^{\text {nd }}$ \\
\hline Reward and Recognition & 10.2 & 22.0 & 10.2 & 20.3 & 37.3 & 118 & 3.53 & $3^{\text {rd }}$ \\
\hline Managerial Style & 1.7 & 15.3 & 32.2 & 32.2 & 18.6 & 118 & 3.51 & $4^{\text {th }}$ \\
\hline Promotion & 13.6 & 13.6 & 8.5 & 37.3 & 27.1 & 118 & 3.46 & $5^{\text {th }}$ \\
\hline $\begin{array}{l}\text { Organizational } \\
\text { and Prestige }\end{array}$ & 3.4 & 22.0 & 16.9 & 40.7 & 16.9 & 118 & 3.37 & $6^{\text {th }}$ \\
\hline Job Satisfaction & 0.0 & 23.7 & 30.5 & 33.9 & 11.9 & 118 & 3.34 & $7^{\text {th }}$ \\
\hline $\begin{array}{l}\text { Hiring Practices } \\
\text { Employee Selection }\end{array}$ & 20.3 & 10.2 & 18.6 & 20.3 & 30.5 & 118 & 3.31 & $9^{\text {th }}$ \\
\hline Work Environment & 13.6 & 22.0 & 16.9 & 23.7 & 23.7 & 118 & 3.22 & $10^{\text {th }}$ \\
\hline $\begin{array}{l}\text { Organizational Values } \\
\text { and Beliefs }\end{array}$ & 23.7 & 13.6 & 13.6 & 23.7 & 25.4 & 118 & 3.14 & $11^{\text {th }}$ \\
\hline $\begin{array}{l}\text { Participation } \\
\text { Decision-making } \\
\text { Valid N (listwise) }\end{array}$ & 6.8 & 18.6 & 39.0 & 25.4 & 10.2 & 118 & 3.14 & $12^{\text {th }}$ \\
\hline
\end{tabular}

Note: $1=$ not important, $2=$ of little importance, $3=$ moderately important, $4=$ important, $5=$ very important

Source: Field Survey, (2018)

\subsection{Test of Hypothesis}

$\mathrm{H}_{01}$ : There is no significant relationship between employee retention factors and employee loyalty factors in the deposit money banks

The results of the test of the hypothesis are presented in Table 3. Pearson Correlation Coefficient and significant probabilities for the relationship between employee retention factors and employee loyalty factors in the deposit money banks are itemised. The result shows that there is a very strong positive relationship (i.e. correlation coefficient, $r=0.830$ ) between employee retention factors and loyalty factors in the banks. The significant probability for this association is 0.00 . Since correlation is significant for this research at 0.01 level (2-tailed) and significant probability for the hypothesis is less than 0.01 (2-tailed), the null hypothesis is rejected, hence, the acceptance of alternate hypothesis that there is significant relationship between employee retention factors and employee loyalty factors in the deposit money banks.

Table 3. Relationship between Employee Retention Factors and Employee Loyalty Factors

\begin{tabular}{llll}
\hline & & Loyalty & Retention \\
\hline \multirow{5}{*}{ Loyalty } & Pearson & 1 & $.830^{* *}$ \\
& Correlation & & .000 \\
& Sig. (2-tailed) & & 118 \\
& N & 118 & 1 \\
& Pearson & $.830^{* *}$ & \\
Retention & Correlation & .000 & 118 \\
& Sig. (2-tailed) & 118 & \\
& N & 118 & \\
\hline
\end{tabular}

**. Correlation is significant at the 0.01 level (2-tailed). 
Source: Field Survey (2018)

\section{Discussion}

The study was aimed at examining the factors motivating employee loyalty and employee retention in deposit money banks in Nigeria. Majority of banks in the country have their corporate headquarters in Lagos and branches all over the country. To this end, employment guidelines are centrally formulated at the headquarters and applied to all employees irrespective of their branch locations. Although there have been studies on motivation and employee loyalty and retention, there has not been generally acceptable criteria among researchers. The findings of this study will reinforce the importance of those factors that keep recurring in studies as the major factors for loyalty and retention in order to stem incessant turnover especially in the Nigerian banking industry. It will further assist human resource managers and management in formulating enduring and practical policies using appropriate motivational factors.

The study found training and development, promotion and job security as the three most important motivational factors for employee loyalty. It also found training and development, job security plus reward and recognition in that order as the major motivational factors for employee retention. The findings are not significantly different from some previous research findings but imply that the motivational factors should be given the importance they deserve in the workplace in general and banks in particular. World economy appears to depend largely on knowledge and innovation which are enhanced through training and development.

The finding of this study is supported by Logan (2000) that employees will remain where there are opportunities to learn and do new things. Other previous findings in support of the present study include Dama and Isah (2015) and Samuel and Chipunza (2009) that training and development stimulate loyalty and decision to stay in employees. This study showed that training and development are critical factors for employee loyalty and retention. Messmer (2000) found that one of the important factors in employee retention is investment on employee training and career development. Garg and Rastogi (2006), explained that in today's competitive environment feedback is very essential for organizations from employees and the more knowledge the employee gets, the more he or she will perform and meet the global challenges of the market place and will be willing to remain with the organisation.

The outcome of this study differs from the study of Khuongi and Tien (2013), which revealed that job satisfaction, supervisor support, training and development, teamwork, and working environment all play crucial roles and significantly affect employees' loyalty, although training and development was named as one of the motivating factors. Also, Waqas et.al (2014) reported that a strong relationship exist between job satisfaction and job loyalty

The current study shows that promotion and job security support employee loyalty while job security, reward and recognition enhance employee retention. Job security is essential and puts the employees at ease in order to do the work well. Promotion, reward and recognition should be the outcome of jobs well done. The findings agree with the studies conducted by Nyamkye (2012), Osinbajo et al. (2014). The findings differ from those of Clarke (2001) that 
retention is dependent on strong interpersonal relationship with colleagues. It also differs from Oginni et al.(2018) that job satisfaction determines employee retention; and Nwangi and Omondi(2016) that financial and non-financial needs influence loyalty and retention.

The finding is different from those that put high premium on other motivational variables such as salary and fringe benefits (Nyamkye, 2012), and organizational environment ( Khongi and Tien, 2013), among others.. The importance of these findings is that employees as human enterprise need some motivating factors to show loyalty and remain with the organizations they are working for. The appropriate factors ought to be identified and provided for them to ensure loyalty and continuity on the job.

\section{Conclusion}

Employee loyalty and retention are necessary for the competitiveness and sustainability of organizations since employees control and use other resources of production. Disloyalty can create problems for the system and turn it to a wasteful venture. It becomes necessary for management to have motivated employees through the identification and provision of factors that enhance loyalty and retention. It is very essential to understand that motivating factors are diverse which tend to show that loyalty and retention are psychological. This study has added to the body of knowledge that motivational factors of training and development and job security are significantly related to employee loyalty and retention in the Nigerian banks. Getting to understand the specific retention strategies is beneficial instead of applying general or blanket strategies that may be disadvantageous in the long run.

\section{Limitations}

The study was limited to four of the 23 deposit money banks in Nigeria. Perhaps involving more banks in the study could have influenced results. Its being difficult to ascertain the genuineness of the respondents in answering the questions and statements of the questionnaire is a limitation.

However, the aforementioned have not reduced the contribution of the study to knowledge.

\section{References}

Adedeji, O. A. (2018). The effect of non-interest income on banks' profitability in Nigeria. Unpublished M.Tech thesis, Federal University of Technology, Akure.

Al-Ma'ani, A. I. (2013). Factors affecting the organizational loyalty of workers in the Jordanian Commercial Banks. Interdisciplinary Journal of Contemporary Research in Business, 4(12), 878-898.

Amadasu, D. E. (2003). Personnel and the Nigerian management crisis: Ajaokuta Iron and Steel Mill examined. Abuja Management Review, 1(4).

Antoncic, J. A., \& Antoncic, B. (2011). Employee loyalty and its impact on firm growth. Intern ational Journal of Management and Information Systems, 15(1), 81-87. https://doi.org/10.19030/ijmis.v15i1.1598 


\section{Macrothink}

International Journal of Human Resource Studies

ISSN 2162-3058

2018, Vol. 8, No. 3

Clarke, K. F. (2001). What businesses are doing to attract and retain employee-becoming an employer of choice. Employee Benefits Journal, 34-37.

Dama, J. L., \& Isah, M. B. (2015). Effect of training and development on employee's retention in Selected commercial banks in Adamawa State. European Journal of Business and Management, 7(36), 96-101.

Fitz-Enz, J. (1990). Getting and keeping good employees. Personnel Journal, 67(8), 25-29.

Garg, P., \& Rastongi, R. (2006). New model of job design motivation employees performance. Journal of Management Development, 62(1), 25-33.

Gberevbie, D. E. (2008). Staff recruitment, retention strategies and performance of selected public and private organizations in Nigeria. Unpublished Ph.D thesis, Covenant University, Ota, Nigeria

Kassa, T. (2015). Employee motivation and its effect on employee retention in Ambo Mineral Water Factory. International Journal of Advance Research in Computer Science and Management Studies, 3(3), 10-21.

Khuong, M. N., \& Tien, B. O. (2013). Factors influencing employee loyalty directly and indirectly through job satisfaction: A study of banking sector in Ho Chi Minh City. International Journal of Current Research and Academic Review, 1(4), 81-95.

Kumar, D. N. S., \& Shekhar, N. (2012). Perspectives envisaging employee loyalty: A case analysis. Journal of Management Research, 12(2), 100-112. Retrieved from http://search.proquest.com/docview/1033786746?accountid=14407

Lockwood, N. R. (2006). Talent management drivers for organisational success. Society for Human Resources Management Research Quarterly Journal, 51(6), 1-11.

Logan, J. K. (2000). Retention tangibles and intangibles: More meaning in work is essential, but good chair massages won't hurt. Training and Development Journal, 54(4), 48-50.

Luna-Arocas, R., \& Camps, J. (2008). A model of high performance work practices and turnover intentions. Personnel Review.

Lyria, R. K. (2013).Effect of talent management on organizational performance in companies listed in Nairobi Securities Exchange in Kenya. Unpublished PhD thesis, Jomo Kenyatta University of Agriculture and Technology, Kenya.

Mehta, S., Singh, T., Bhakar, S., \& Sinha, B. (2010). Employee loyalty towards organization. International Journal for Business Management and Economic Resources, 1(1), 98-108.

Messmer, M. (2000). Orientations programs can be key to employee retention. In Strategic Finance Journal, 81(8), 12-15.

Mwangi, E. K., \& Omondi, M. (2016). Factors influencing staff retention in the banking industry in Kenya: A case study of Equity Bank Limited. The Strategic Business and Change Journal of Management, 3(20), 428-454. 


\section{Macrothink}

International Journal of Human Resource Studies

ISSN 2162-3058

2018, Vol. 8, No. 3

National Bureau of Statistics (2010). National Data Bank of Nigeria.

Ng'ethe, J. M. (2013). Determinants of academic staff retention in public university in Kenya. Unpublished PhD thesis, Jomo Kenyatta University of Agriculture and Technology, Kenya.

Nyamekye, F. (2012). Impact of motivation on employee retention: A case study of Standard Chartered Bank, Ghana Limited. Unpublished Master thesis, Kwame Nkrumah University of Science and Technology, Ghana.

Oginni, B. O., Dunmade, E. O., \& Ogunwole, A. C. (2018). The Role of employees work expectations in job satisfaction and labour turnover in the service industry: A case of selected organisations in Lagos, Ogun and Oyo States, Nigeria. World Journal of Business and Management, 4(1).

Osinbanjo, A. O., Salau, O. P., \& Falola, H. O. (2014). Modeling the relationship between motivating factors, employee' retention, and job satisfaction in the Nigerian Banking Industry. Journal of Management Policies and Practice, 2(2), 63-83.

Robbins, S. P., Judge, T. A., \& Sanghi, S. (2007). Essentials of Organizational Behavior. Florida: Pearson Education.

Samuel, M.O., \& Chipunza, C. (2009). Employee retention and turnover: Using motivational variables as a panacea. African Journal of Management, 3(8), 410-415. DOI:10.5897/AJBM09.125

Sinha, C., \& Sinha, R. (2012). Factors affecting employee retention: A comparative analysis of two organizations from heavy engineering industry. European Journal of Business and Management, 4(3), 146-163.

Smith, J. A. (1965). Inequity in social exchange In L. Berkowitz (Ed.), Advances in experimental. Social Psychology Journal, 2(267-299). New York: Academic Press.

Uzma, W. A. (2015). Impact of training on employee's performance. Business Management and Strategy, 6(1), 49-64.

Waqas, A., Bashir, U., \& Sattar, M. F. (2014). Factors influencing job satisfaction and its impact on job loyalty in Pakistan. International Journal of Learning and Development, 4(2), 141-161. https://doi.org/10.5296/ijld.v4i2.6095

\section{Copyright Disclaimer}

Copyright for this article is retained by the author(s), with first publication rights granted to the journal.

This is an open-access article distributed under the terms and conditions of the Creative Commons Attribution license (http://creativecommons.org/licenses/by/4.0/). 